\title{
Okul öncesi dönem çocuklarının liderlik özellikleri ile dil becerileri arasındaki ilişkinin incelenmesi*
}

\section{Investigation of the relationship between leadership qualities and}

\author{
language skills of preschool children
}

\section{Makale Geçmişi \\ Geliş : 15 Ocak 2020 \\ Düzeltme : 6 Haziran 2020 \\ Kabul : 12 Haziran 2020}

\section{Makale Türü}

Araştırma Makalesi
Article History

Received : 15 January 2020

Revised : 6 June 2020

Accepted : 12 June 2020

\section{Article Type}

Research Article

\author{
Ayşenur Duran ${ }^{1}$, Rengin Zembat ${ }^{2}$
}

\begin{abstract}
Öz: Bu araştırmanın amacı okul öncesi dönem çocuklarının liderlik özellikleri ile dil becerileri arasındaki ilişkinin incelenmesidir. Araştırmaya İstanbul'daki okul öncesi eğitim kurumlarına devam eden, yaşları 48-66 aylık olan 92 çocuk katılmıştır. Araştırmada veri toplama araçları olarak Kişisel Bilgiler Formu, Erken Çocukluk Dönemi Liderlik Ölçeği ve Türkçe Erken Dil Gelişimi Testi (TEDİL)'nin İfade Edici Dil Alt Testi kullanılmıştır. Araştırmanın sonuçlarında Erken Çocukluk Dönemi Liderlik Ölçeği’nden elde edilen verilere göre çocuklarının liderlik puanlarının yüksek düzeyde olduğu, çocukların liderlik puan ortalamalarının yaş, cinsiyet ve okul öncesi eğitim kurumuna devam süresi değişkenlerine göre anlamlı bir farklılık gösterdiği saptanmıştır. Türkçe Erken Dil Gelişimi Testi'nden elde edilen verilere göre ise çocukların ifade edici dil puanlarının cinsiyet ve okul öncesi eğitim kurumuna devam süresi değişkenlerine göre anlamlı farklılık gösterdiği, yaş değişkenine göre ise anlamlı farklılık göstermediğ tespit edilmiştir. Çocukların liderlik özellikleri ile dil becerileri arasında ise liderlik özellikleri ile dil becerileri arasında anlamlı bir ilişki bulunmuştur.
\end{abstract}

Anahtar Kelimeler: Erken çocukluk dönemi, Liderlik, Dil becerileri.

Abstract: The purpose of this research was to examine the relationship between leadership qualities and language skills in preschool children. Ninety-two 48-66-month-old children who attend preschools in Istanbul, participated in the study. The Personal Information Form, the Early Childhood Leadership Scale and the Early Language Development Test's expressive language subtest were used as data collection tools in this study. The study, investigated whether the leadership qualities and language skill levels of the children varied significantly depending on age, gender and duration of the preschool education. According to the data obtained from the Early Childhood Leadership Scale, the leadership scores of the preschool children were high, and the mean leadership scores were found to significantly depend on the variables of age, gender, and duration of preschool education. According to the data obtained from the The Early Language Development Test, the children's expressive language scores showed significant differences according to the variables of gender and duration of preschool education. There was no significant difference in this data according to the variable of age. According to the analyses conducted, a significant relationship was found to exist between children's leadership qualities and language skills.

Keywords: Early childhood, Leadership, Language skills.

\footnotetext{
* Bu çalışma ilk yazarın Marmara Üniversitesi Eğitim Bilimleri Enstitüsü’nde tamamladığı doktora tezinden türetilmiştir.

${ }^{1}$ İstanbul İl Mem, aysenurokuloncesi@hotmail.com, ORCID: 0000-0001-6504-6120

${ }^{2}$ Maltepe Üniversitesi, Eğitim Fakültesi, Temel Eğitim Bölümü, renginzembat@maltepe.edu.tr, ORCID: 0000-0002-2377-8910
} 


\section{SUMMARY}

\section{Introduction}

In the literature, many criteria and qualities have been proposed and defined for effective leadership. But among them, verbal language skills play an important role because of the leadership style of the leaders and their impact on the output of the leadership. Verbal language skills or speaking skills are seen as an important characteristic and criteria that a leader should possess (Berkelaar, Williams and Linvill, 2009; Bolden et al., 2003). Since leadership is the process of influencing others to achieve certain goals (Özalp, et al., 2004), it may be very difficult for someone who does not have good verbal skills to affect others. Language is a tool that is used to mediate all the relationships that an individual establishes with his or her environment. It is used to regulate social ties and functional superiority through, for example, communicative interaction and immediate feedback between the leader and his followers (Özel, 2013). Language is one of the most important development areas in preschool period and language skills are also important for child leadership. There are also studies show that there is a relationship between speaking skills and peer popularity of children with normal development (Black and Hazen, 1990; Hazen \& Black, 1989; Place \& Becker, 1991). The results of these studies have shown that socially-accepted children have better skills in starting, maintaining and restarting a consistent speech than less-accepted children. In addition, in the study by Perez, Chassin, Ellington and Smith (1982), the link between verbal skills, establishing social contacts and initiating leadership behavior in young children was observed. But in Turkey for such matters did not find any work. In this study both the leadership characteristics and language skills of preschool children were examined according to various variables and the relationship between leadership characteristics and language skills was investigated.

\section{Method}

The study is planned in correlational research. Ninety-two 48-66-month-old children who attend preschools in Istanbul participated the study. The Personal Information Form, the Early Childhood Leadership Scale and The Early Language Development test's expressive language subtest were used as data collection tools in this study. In the analysis of the data, correlation and regression techniques were used besides descriptive values.

\section{Results}

According to the data obtained from the Early Childhood Leadership Scale, the leadership scores of the preschool children participating in the study were high, and the mean scores of the leadership scores of the children were found to be significant according to the variables of age, gender and duration of the preschool education. According to the data obtained from the The Early Language Development Test, the expressive language scores of the children showed significant differences according to the variables of gender and duration of preschool education. There was no significant difference according to the variable of age. 
According to the analysis, there was a significant relationship between children's leadership qualities and language skills.

\section{Conclusion and Discussion}

This study analyzed the relationship between children's leadership qualities and language skills, and found a moderate positive correlation between these two factor. In other words, the language scores of children increased as their leadership scores increased. Similar to the results obtained from this study, Perez, et al. (1982) and Rosenthal (1957) reported that children who were identified as leaders in sociometry tests scored higher in language tests.

Within the scope of this research, the participating children had high leadership scores. Although there is no research to support this finding for preschool children in particular, some studies have shown show that students acrosS different age groups have high leadership qualities (Avc1, 2009; Birol, 2005; Cansoy, 2015; Durmuş, 2011; Ogurlu, 2012; Solmaz, 2017). It was also found that the average leadership scores of the children differed statistically according to their age. Parten (1933) and French (1984) both concluded that children who are leaders in the classroom are often older than others. More research is needed regarding this variable. The mean leadership scores of the children also differed according to gender. This finding overlaps with some research results (Fu, 1979; Mawson, 2010; Mawson, 2011; Sheldon, 1996: as cited in Soffler 2011) but conflict with others (Harrison, Rawls \& Rawls, 1971; Parten, 1933; Trawick-Smith, 1992). This result is thought to stem from the differences in language development between girls and boys and the power this process has in influencing others. İt was also determined that the cildren's leadership scores differed significantly according to the duration of their preschool education. Although there is no direct correlation between leadership and the duration of preschool education, some studies have shown that the relationships and interactions that children have with their peers are important.. In their study of three-anda-half-year-olds, Schwartz, Strickland and Krolick (1974) concluded that children who started preschool education before reaching 22 month displayed more positive outcomes, less tension and more social interaction than children who started preschool later. Howes (1991) stated that the duration of preschool education affects children's relationships with peers both positively and negatively (Bohlin, 2000). This result may be because children who are able to be in preschool for longer periods than others gain more experience in social environments and benefit more from preschool education.

According to the results of the study, the expressive language scores of the children did not differ significantly according to the age. This finding overlaps with some other research findings (Çat Şahin, 2008; Gürocak, 2007) but disagrees with others (Koçak, Ergin, Yalçın, 2014; Yıldırım, 2008). This result may be due to the characteristics of the children in the study group. It was found that children's expressive language scores differed statistically according to their gender. This difference was in favor of the girls is the study. In the relevant literature it can be seen that differences in children's language skills favor both boys and girls. Özmermer (2008), Koçak, Ergin and Yalçın (2014) and Yıldırım, et al. (2010) concluded that boys' language scores were higher than girls' scores. In contrast to these results, Çat Şahin (2008) and Erdoğan, 
Şimşek Bekir and Erdoğan Aras (2005) found that there was no significant difference in children's language scores according to gender. It can be said that this result is due to the differences in the use of language between girls and boys. It was found that the expressive language scores of the children in the study group differed statistically according to the duration of preschool education variable. This difference was in favor of a longer period of preschool education. This finding is similar to results which by Çat Şahin (2008), Erdoğan, Şimşek Bekir and Erdoğan Aras (2005), and Öztürk (1995). In contrast, Yıldız, Şen and Coşkun (2006) could not conclude that there were significant differences. It is thought that this result is due to longer experiences in rich stimulating preschool education environment.

As there is a relationship between children's leadership characteristics and language skills, teachers (as key role models in children' lives) can participate in courses and seminars on these topics. The courses cover both leadership and the use of language support the development of these skills in children, and propose various activities for educational environments.

Future studies should be carried out in different provinces outside of Istanbul. These studies should examine larger groups of students, children from different socioeconomic backgrounds, and many other correlating factors that may have an impact on leadership.

This research was conducted using quantitative research methods. New research could also be conducted using qualitative research methods, and long-term effects could be observed by implementing longitudinal studies. 


\section{GİRİŞ}

Genel anlamda liderlik, “ortak bir hedefe ulaşmak için başkalarının yardım ve desteğini alan bir sosyal etki türü” olarak tanımlanabilir (Murphy ve Johnson, 2011). Liderlikle ilgili kapsamlı araştırmalara rastlamak mümkündür ve bu çalısmaların çoğu iş yaşamındaki liderler veya yöneticiler üzerine odaklanmış veya yapılandırılmıştır. Ancak küçük çocuklarda liderliği ele alan çok fazla araştırma yoktur (Lee, Recchia, ve Shin, 2005; Mullarkey, Recchia, Lee, Shin, ve Lee, 2005). Çocuklar çok küçük yaşlardan itibaren liderlik becerileri sergiler ve bu yetişkinlikteki liderliğin gelişimi hakkında fikir verebilir (Barthold, 2014). Tipkı çocukların diğer önemli becerileri öğrenmesi gibi, liderlik becerilerini deneyimleriyle öğrenip geliştirebilmeleri için gelişimin erken dönemleri çok önemlidir (Murphy ve Johnson, 2011).

Çocukların çevrelerini etkileme güçleri bebeklik döneminde ortaya çıkmaktadır. Yenidoğan bir bebek ihtiyaçlarını ağlayarak çevresindekilere iletmeye çalışır ve kısa bir süre içinde de ağlamasının beslenme, temizlik gibi ihtiyaçlarının karşılanması konusunda dikkat çektiğini keşfeder. Çocuk büyüdükçe sosyal hayattaki insanlardan ilham almayı ve onlarla etkileşim kurmayı öğrenir. Çocuğun sosyal ağı arttıkça bu etki alanı onun akran etkileşimlerini de arttırmaktadır. Özellikle çocukların daha küçük yaşlardan itibaren okul öncesi eğitim ortamlarına katılması ile birlikte akranlarıla olan sosyal etkileşimleri daha erken yaşlarda başlamakta ve daha uzun süre devam etmektedir. 5 yaş ve daha küçük çocukların erken sosyal ilişkileri, özellikle de akranlarla olan ilişkileri, çocukların sosyal, duygusal ve bilişsel gelişimlerinin önemli yönü olarak kabul edilir (Hartup, 1992; Piaget, 1932; Sullivan, 1953: akt. Shin, Recchia, Lee, Lee ve Mullarkey, 2004). Bu sosyal ilişkilerde çocuklar akranlarını hem etkilerler, hem de onlardan etkilenirler. Başkaları tarafindan yönlendirilen ya da itaatkar davranışlar gösteren çocukların olduğu ortamlarda genellikle bir ya da birden fazla sosyal liderler ortaya çıkar (Fu, 1970). Liderlik çocuklar için de önemli bir sosyal davranıştır (Fu, 1970).

Bireyin etkili liderlik göstermek için belirli niteliklere sahip olması ve sergilemesi gerekir (Koçel, 2010). Araştırmacılar, bireylerin etkili lider olmalarını sağlayan pek çok farklı özellikleri ve önemlerini farklı şekillerde vurgulamaktadırlar. Çocuk liderliği üzerine yapılan çalışmalarda da neredeyse yapılan her çalışmada çocukların liderlik özelliklerinden bahsedilmiştir. Bu özellikler lider çocukların sıkça ihtiyaç duyduğu ya da sergilediği beceriler ya da nitelikler olarak değerlendirilir. Sözel dil becerileri lider çocukların özelliklerinden biri olarak pek çok çalışmada yer alan ve çeşitli araştırmalarda liderlik becerileri üzerine etkisi tartışılmış bir özellik olarak karşımıza çıkmaktadır (Fu, Canaday ve Fu (1982); Karnes ve Bean (1990); Kemple (1991); Kitano (1983): akt. Hensel (1991); Lee, Recchia ve Shin (2005); Perez, Chassin, Ellington ve Smith (1982); Shin, Recchia, Lee, Lee ve Mullarkey (2004); Sisk ve Rosselli (1996); Wolfle (1989): akt. Hensel, 1991). Ayrıca çocuk 
liderler, literatürde yaygın olarak "akranlarıyla iyi sözlü iletişim kurar" şeklinde tanımlanmaktadır (Adcock ve Segal, 1983; Karnes ve Bean, 1996; Manning, 2005; Perez, Chassin, Ellington ve Smith, 1982; Roets, 2000; Shin, Recchia, Lee, Lee ve Mullarkey, 2004; Sisk ve Rosselli, 1996).

Çocuğun dilde ne kadar çok ustalı̆̆1 varsa, liderlik vizyonunu tanımlama ve gerçekleştirmeyi kolaylaştırmada o kadar etkili olur. Çocuğun sözcük dağarcığı, duygusal nüansları kullanma ve yorumlama kapasitesinde yaşayabileceği sıkıntılar, çocuğun liderlik etme kabiliyetini azaltabilecektir. Bir lider çocuk için dil, mesajlar düzenlemek, iletmek ve başkalarını motive etmek için (hem sözcüklerde hem de duygu vasitasıyla) önemlidir (Soffler, 2011). Liderlik belirli amaçları gerçekleştirmek üzere başkalarını etkileme süreci olduğundan (Özalp, Şahin, Berberoğlu ve Ceylan, 2004) sözel becerileri yeterli düzeyde olmayan birinin başkalarını etkilemesi de çok zor olabilir. Bir liderin sözlü iletişim becerisine sahip olmasının oldukça önemli olduğu bir örnek Samoa kültüründen verilebilir. Samoa kültüründe liderin sözlü iletişim becerisi o kadar önemli ve değerlidir ki, bu kültürde lidere "konuşan şef" denir (Addison, Oliver ve Cooper, 1987).

Okul öncesi dönem çocukları konuşabilme becerilerini arkadaş edinmek için kullanırlar. $\mathrm{Bu}$ nedenle, eğer çocuklar iletişim yeterliliğine sahip değillerse, çoğunlukla akran grubuna girmeleri engellenecektir (Howes, 1988). Çocukların dilsel yetkinliğinin, toplumsal kabulün kurulmasında merkezi bir rol oynayabileceğini de göstermektedir (Gertner, Rice ve Hadley, 1994). Çocukların dilsel yetkinlikleri ve akran etkileşimi modelleri arasındaki yakın ilişki, okul öncesi sınıflarında yürütülen bir dizi çalışmada gösterilmiştir (Hadley ve Rice, 1991; Rice, 1993; Rice, Sell ve Hadley, 1991). Normal gelişim gösteren çocukların konuşma yetenekleri ve akran popülerliği arasında ilişki olduğunu gösteren çalışmalara da rastlanmaktadır (Black ve Hazen, 1990; Hazen ve Black, 1989; Place ve Becker, 1991). Bu çalışmaların sonuçları, sosyal olarak kabul görmüş çocukların, daha az kabul görmüş çocuklara oranla tutarlı bir konuşma başlatma, sürdürme ve yeniden başlatma konusunda daha iyi becerilere sahip olduklarını göstermiştir. Ayrıca Perez, Chassin, Ellington ve Smith (1982) tarafindan yapılan çalışmada küçük çocuklarda sözel beceri, sosyal temasların kurulması ve liderlik davranışının başlatılması arasındaki bağlantı gözlemlenmiştir. Fakat söz konusu konuya ilişkin Türkiye'de herhangi bir çalışmaya rastlanmamıştır. Bu noktadan hareketle bu araştırmada çocukların sözel becerilerinin liderlik ile ilişkisi olup olmadığının tespit edilmesi amaçlanmaktadır. Bu temel amaç doğrultusunda asağıdaki alt problemlere cevap aranmaktadır:

- "Çocukların liderlik özellikleri ne düzeydedir?

- Çocukların liderlik özellikleri demografik özelliklere göre (yaş, cinsiyet, okul öncesi eğitim kurumuna devam süresi) farklılık göstermekte midir? 
- Çocukların dil beceri düzeyleri demografik özelliklere göre (yaş, cinsiyet, okul öncesi eğitim kurumuna devam süresi) farklılık göstermekte midir?

- Çocukların liderlik özellikleri ile dil becerileri arasında bir ilişki var mıdır?

\section{YÖNTEM}

\section{Araştırma Deseni}

Bu araştırmada, okul öncesi dönem çocuklarının (48-66 aylık) liderlik özelliklerinin çocukların dil becerileri ile ilişkisi incelendiğinden ilişkisel tarama modelinden yararlanılmıştır. Korelasyonel (ilişkisel) tarama modeli yöntemi eğitim araştırmalarında yaygın olarak tercih edilen bir araştırma modelidir (Creswell, 2005). Korelasyonel tarama, iki veya daha fazla değişken arasındaki değişim varlığını ve/veya derecesini belirlemeyi sağlamaktadır (Karasar, 2014).

\section{Çalışma Grubu}

Bu araştırmanın çalışma grubu 2018-2019 eğitim-öğretim yllında İstanbul'da kolay ulaşılabilirlik ilkesi doğrultusunda belirlenen Fatih ve Beşiktaş ilçelerindeki okullardan ebeveynleri tarafından araştırmaya katılmalarına izin verilen, öğretmen beyanlarına göre normal gelişim gösteren 48-66 aylık 92 çocuktan oluşmaktadır. Çocukların demografik özelliklerine (yaş, cinsiyet, okul öncesi eğitime devam süresi) göre dağıllımıyla ilgili bilgiler Tablo 1'de sunulmuştur.

Tablo 1. Çalş̧ma Grubunda Yer Alan Çocukların Demografik Özellikleri

\begin{tabular}{lccc}
\hline \multicolumn{1}{c}{ Tablolar } & Gruplar & Frekans (n) & Yüzde (\%) \\
\hline Yaş & $48-53$ ay & 7 & 7,6 \\
& $54-59$ ay & 29 & 31,5 \\
& $60-66$ ay & 56 & 60,9 \\
& Toplam & 92 & 100,0 \\
\hline \multirow{2}{*}{ Cinsiyet } & Klz & 49 & 53,3 \\
& Erkek & 43 & 46,7 \\
& Toplam & 92 & 100,0 \\
\hline Okul Öncesi Eğitime & 1 Yil & 53 & 57,6 \\
Devam Süresi & 2 Yil & 32 & 34,8 \\
& 3 Yll & 7 & 7,6 \\
& Toplam & 92 & 100,0 \\
\hline
\end{tabular}

Tablo 1'de görüldüğgu gibi çalışma grubunda yer alan çocukların 7'si $(\% 7,6) 48-53$ aylık, 29'u (\%31,5) 54-59 aylık, 56's1 (\%60,9) ise 60-66 aylıktır. Çocukların 49'u (\%53,3) kız, 43'ü (\%46,7) erkektir. Çocukların 53’ü $(\% 57,6) 1$ yıldır, 32'si $(\% 34,8) 2$ yıldır, 7’si $(\% 7,6)$ ise 3 yıldır okul öncesi eğitim aldığ1 görülmektir. 


\section{Veri Toplama Araçları}

Araştırmada, araştırmacı tarafından geliştirilen "Kişisel Bilgiler Formu”, yine araştırmacı tarafından geliştirilen ve geçerlik ve güvenirlik çalışmaları yapılan "Erken Çocukluk Dönemi Liderlik Ölçeği”" ile “TEDİL” kullanılmıştır. Erken Çocukluk Dönemi Liderlik Ölçeği araştırmaya katılan çocukların okul öncesi öğretmenleri tarafından, Türkçe Erken Dil Gelişimi Testi (TEDİL)'nin İfade Edici Dil Alt Testi ise araştırmacı tarafından çocuklarla birebir uygulanmıştır.

\section{Kisisel Bilgiler Formu}

Çalışma grubunda yer alan çocukların yaş, cinsiyet ve okul öncesi eğitime devam süresi hakkında bilgi toplamak amacıyla araştırmacı tarafından geliştirilmiştir.

\section{Erken Çocukluk Dönemi Liderlik Ölçeği}

Çocukların liderlik özelliklerini tespit etmek ve değerlendirmek amacıyla araştırmacı tarafından geliştirilen ve geçerlik ve güvenirlik çalışması yapılan, 48-66 ay grubu çocuklara uygun olarak hazırlanmış toplam 48 maddeden oluşan bir ölçme aracıdır. Ölçek okul öncesi öğretmeninin, sınıfinda bulunan her çocuk için bireysel olarak dolduracağı, 5’li Likert tipinde bir ölçektir. Faktör analizi sonucunda ölçeğin tek faktörlü yapısının olduğu belirlenmiştir. Ölçeğin iç tutarlık katsayısı .99 olarak bulunmuştur.

\section{Türkçe Erken Dil Gelişimi Testi (TEDIL)}

Türkçe Erken Dil Gelişimi Testi (TEDILL; Topbaş ve Güven, 2013), Hresko, Reid ve Hammill, (1999) tarafindan geliştirilen Test of Early Language Development (TELD-3) dil gelissim testinin Türkçe'ye uyarlamasıdır. Test 2 yas 0 ay ile 7 yas 11 ay arasındaki çocukların alıcı ve ifade edici dil becerilerini ölçmek amacıyla Amerika'da geliştirilmiş bir araçtır. TEDIL A ve B olmak üzere paralel formlardan oluşmaktadır. Her bir formun da Alıcı ve İfade Edici dil olmak üzere iki alt testi mevcuttur. Her bir formda toplam 76 madde bulunmaktadır. TEDIL testinin uygulamas1 15-40 dakika arasında sürmektedir.

Topbaş ve Güven (2013) tarafından yapılan uyarlama çalışması sonucunda testin her iki form ve alt testler için iç tutarlılık katsayılarının .86 ile .98 arasında değişen iç tutarlılığa sahip olduğu tespit edilmiştir. Geçerlilik çalışmasında ise tüm örneklem grubu kullanılarak alt testlerden elde edilen puanların iç korelasyonu her iki form için .87 ile .91 arasında bulunmuştur (Güven, 2014).

\section{Verilerin Toplanmas1}

Araştırma öncesinde İstanbul İl Milli Eğitim Müdürlüğü’nden gerekli izinler alınmış, ardından araştırmaya dahil edilen okullardaki çocukların ailelerine araştırma hakkında açıklayıcı bilgiler içeren ve çocukların araştırmaya katılımı için onay istenen 'Ebeveyn Bilgilendirme ve İzin Formu' 
gönderilmiştir. Araştırmaya katılması ailesi tarafından onaylanan çocuklar araştırmaya dahil edilmiştir

Erken Çocukluk Dönemi Liderlik Ölçeği çocuklar adına doldurması için öğretmenlere verilmiştir. Türkçe Erken Dil Gelişimi Testi ise uygulayıcı sertifikası olan araştırmacı tarafindan çocuklarla bire bir uygulanmıştır.

\section{Verilerin Analizi}

Araştırmada elde edilen verilerin analizinde SPSS paket programı kullanılmıştır. Betimsel analizler sonucunda verilerin normallik koşulunu sağladığı görülmüş, analizler parametrik testler ile yapılmıştır.

Verilerin analizinde iki bagı̆msız grup arasında niceliksel sürekli verilerin karșılaș,ırılmasında t-testi, ikiden fazla bağmsız grup arasında niceliksel sürekli verilerin karşıllaș,ırılmasında Tek yönlü (One way) Anova testi kullanılmıs,tır. Anova testi sonrasında farklılıkları belirlemek üzere tamamlayıcı post-hoc analizi olarak Scheffe testi kullanılmış,ır. 48-66 aylık çocukların liderlik özellikleri ile dil becerileri arasındaki ilişki ise Pearson Çarpım Momentler Korelasyon katsayısı ve Basit Doğrusal Regresyon analizi yöntemleri ile incelenmis,tir.

\section{BULGULAR}

Çalışma Grubunun Erken Çocukluk Dönemi Liderlik Ölçeği’nden aldıkları puanlara ilişkin betimsel bulgular aşağıda yer almaktadır.

Araştırmaya katılan çocukların liderlik puanlarına ilişkin bilgiler Tablo 2'de sunulmuştur.

Tablo 2. Erken Çocukluk Dönemi Liderlik Puan Ortalaması

\begin{tabular}{cccccc}
\hline & N & Ort & Ss & Min. & Max. \\
\hline Toplam Puan & 92 & 3,25 & 1,02 & 1,42 & 4,78 \\
\hline
\end{tabular}

Çocukların liderlik puan ortalamalarının değeri; 0,00-1,00 arasında ise çok düşük, 1,01-2,00 arasında ise düşük, 2,01-3,00 arasında ise orta, 3,01-4,00 arasında ise yüksek, 4,01-5,00 arasında ise çok yüksek düzeyde olduğu şeklinde yorumlanmıştır. Tablo 2'de görüldügü gibi araştırmaya katılan çocukların liderlik düzeyleri yüksek $(3,25 \pm 1,022)$ düzey olarak saptanmıstır.

Liderlik puanlarının yaşa göre anlamlı farklılık gösterip göstermediği belirlemek için yapılan analiz sonuçları Tablo 3’te verilmiştir. 
Tablo 3. Yaşa Göre Erken Çocukluk Dönemi Liderlik Düzeyi Anova Testi Sonucu

\begin{tabular}{cccccccc}
\hline & Grup & N & Ort & Ss & F & p & Fark \\
\hline Erken Çocukluk Dönemi & $48-53$ ay & 7 & 3,25 & 1,05 & & & \\
Liderlik Düzeyi & $54-59$ ay & 29 & 3,05 & 1,02 & 3,68 & $\mathbf{0 , 0 2}$ & $\mathbf{3}>\mathbf{2}$ \\
& $60-66$ ay & 56 & 3,34 &, 99 & & &
\end{tabular}

Tablo 3’te görüldüğü gibi araştırmaya katılan çocukların liderlik puan ortalamalarının yaş değişkenine göre anlamlı bir farklılık gösterip göstermediğini belirlemek amacıyla yapılan analiz sonucunda grup ortalamaları arasındaki fark istatistiksel açıdan anlamlı bulunmuştur ( $F=3,68$; $\mathrm{p}=0,02<0,05)$. Farklılıkların kaynaklarını belirlemek amaciyla tamamlayıc1 post-hoc analizi yapılmıştır. Yaşı 60-66 ay arasında olanların liderlik puanları (3,34 \pm 0,99), yaşı 54-59 ay arasında olanların liderlik puanlarından $(3,05 \pm 1,02)$ yüksek bulunmuştur.

Cinsiyet degişkenine göre liderlik puanlarının farklılaşma durumuna dair bilgiler Tablo 4'te sunulmuştur.

Tablo 4. Cinsiyete Göre Erken Çocukluk Dönemi Liderlik Düzeyi t Testi Sonucu

\begin{tabular}{cccccccc}
\hline & Grup & N & Ort & Ss & t & p & Fark \\
\hline $\begin{array}{c}\text { Erken Çocukluk Dönemi } \\
\text { Liderlik }\end{array}$ & Krz & 49 & 3,39 &, 60 & & & \\
& Erkek & 43 & 2,93 &, 79 & 3,12 &, 00 & $\mathbf{1}>\mathbf{2}$ \\
\hline
\end{tabular}

Tablo 4'te görüldüğü gibi araştırmaya katılan çocukların liderlik puanları ortalamalarının cinsiyet değişkenine göre anlamlı bir farklılık gösterip göstermediğini belirlemek amacıyla yapılan t-testi sonucunda grup ortalamaları arasındaki fark istatistiksel açıdan anlamlı bulunmuştur $(t=3,12$, $\mathrm{p}=, 00<0,05)$. Çocukların liderlik puan ortalamaları incelendiğinde kız çocuklarının puan ortalamalarının 3,39, erkek çocuklarının puan ortalamalarının 2,93 olduğu görülmektedir. Buna göre kız çocuklarının liderlik puanları erkek çocuklarınınkinden daha yüksektir.

Tablo 5'te çocukların liderlik puanlarının okul öncesi eğitime devam süresi değişkenine göre farklılaşma durumuna ilişkin bilgiler yer almaktadır.

Tablo 5. Okul öncesi Eğitime Devam Süresine Göre Erken Çocukluk Dönemi Liderlik Düzeyi Anova Sonucu

\begin{tabular}{cccccccc}
\hline & Grup & N & Ort & Ss & F & p & Fark \\
\hline \multirow{2}{*}{$\begin{array}{c}\text { Erken Çocukluk Dönemi } \\
\text { Liderlik }\end{array}$} & 1 Yil & 53 & 3,06 & 1,00 & & & \\
& 2 Yil & 32 & 3,27 & 1,03 & 3,43 & $\mathbf{0 , 0 3}$ & $\mathbf{3}>\mathbf{1}$ \\
& 3 Yil & 7 & 3,52 &, 98 & & & \\
\hline
\end{tabular}

Tablo 5’te görüldüğü gibi araştırmaya katılan çocukların liderlik puan ortalamalarının okul öncesi eğitime devam süresi değişkenine göre anlamlı bir farklılık gösterip göstermediğini belirlemek amacıyla yapılan analiz sonucunda grup ortalamaları arasındaki fark istatistiksel açıdan anlamlı 
bulunmuştur $(\mathrm{F}=3,43 ; \mathrm{p}=0,03<0,05)$. Farklilıkların kaynaklarını belirlemek amacıyla tamamlayıc1 post-hoc analizi yapılmışır. Okul öncesi eğitime 3 yıldır devam eden çocukların liderlik puanları $(3,52 \pm 0,98)$, okul öncesi eğitime 1 yıldır devam eden çocukların liderlik puanlarından $(3,17 \pm 1,00)$ yüksek bulunmuştur.

Çalışma Grubunun TEDİL'den aldıkları puanlara ilişkin betimsel bulgular aşağıda yer almaktadır. Çocukların ifade edici dil puanlarının yaşa göre anlamlı farklılık gösterip göstermediği belirlemek için yapılan analiz sonuçları Tablo 6'da verilmiştir.

Tablo 6. Yaşa Göre TEDİL İfade Edici Dil Alt Testi Anova Testi Sonucu

\begin{tabular}{ccccccc}
\hline & Grup & N & Ort & Ss & F & p \\
\hline TEDİL İfade Edici Dil Alt & $48-53$ ay & 7 & 1,57 &, 97 & & \\
Testi & $54-59$ ay & 29 & 1,96 &, 77 & 1,06 & 0,34 \\
& $60-66$ ay & 56 & 2,01 &, 72 & & \\
\hline
\end{tabular}

Tablo 6'da görüldüğü gibi araştırmaya katılan çocukların TEDİL İfade Edici Dil Alt Testi puanlarının yaş değişkenine göre anlamlı bir farklılık gösterip göstermediğini belirlemek amacıyla yapılan analiz sonucunda grup ortalamaları arasındaki fark istatistiksel açıdan anlamlı bulunmamıştır $(\mathrm{p}>0,05)$.

Cinsiyet değişkenine göre çocukların ifade edici dil testi puanlarının farklılaşma durumuna ilişkin bilgiler Tablo 7'de sunulmuştur.

Tablo 7. Cinsiyete Göre TEDİL İfade Edici Dil Alt Testi t Testi Sonucu

\begin{tabular}{cccccccc}
\hline & Grup & N & Ort & Ss & t & p & Fark \\
\hline $\begin{array}{c}\text { TEDİL İfade Edici Dil Alt } \\
\text { Testi }\end{array}$ & Klz & 49 & 2,22 &, 65 & 3,68 & $\mathbf{0 , 0 0}$ & $\mathbf{1}>\mathbf{2}$ \\
\hline
\end{tabular}

Tablo 7'de görüldüğü gibi araştırmaya katılan çocukların TEDİL İfade Edici Dil Alt Testi puanlarının cinsiyet değişkenine göre anlamlı bir farklılık gösterip göstermediğini belirlemek amacıyla yapılan t testi sonucunda grup ortalamaları arasındaki fark istatistiksel açıdan anlamlı bulunmuştur ( $\mathrm{t}=3,68, \mathrm{p}=0,00<0,01)$. Çocukların cinsiyetlerine göre TEDİL İfade Edici Dil Alt Testi puan ortalamaları incelendiğinde kız çocuklarının puan ortalamalarının 2,22, erkek çocuklarının puan ortalamalarının 1,67 olduğu görülmektedir. Buna göre kız çocuklarının TEDİL İfade Edici Dil Alt Testi puanları, erkek çocuklarınkinden daha yüksektir.

Çocuğun okul öncesi eğitime devam süresi değişkenine göre ifade edici dil testi puanlanının farklılaşma durumuna ilişkin bilgiler Tablo 8'de sunulmuştur. 
Tablo 8. Okul öncesi Eğitime Devam Süresine Göre TEDİL İfade Edici Dil Alt Testi Anova Sonucu

\begin{tabular}{cccccccc}
\hline & Grup & N & Ort & Ss & F & p & Fark \\
\hline & $1 Y_{11}$ & 53 & 1,83 &, 75 & & & \\
TEDİL İfade Edici Dil Alt Testi & $2 Y_{11}$ & 32 & 2,06 &, 71 & 3,48 & $\mathbf{0 , 0 3}$ & $\mathbf{3}>\mathbf{1}$ \\
& $3 Y_{11}$ & 7 & 2,57 &, 78 & & & \\
\hline
\end{tabular}

Tablo 8'de görüldüğü gibi araştırmaya katılan çocukların TEDİL İfade Edici Dil Alt Testi puanlarının okul öncesi eğitime devam süresi değişkenine göre anlamlı bir farklılık gösterip göstermediğini belirlemek amacıyla yapılan analiz sonucunda grup ortalamaları arasındaki fark istatistiksel açıdan anlamlı bulunmuştur $(\mathrm{F}=3,48 ; \mathrm{p}=0,03<0,05)$. Farklılıkların kaynaklarını belirlemek amacıyla tamamlayıcı post-hoc analizi yapılmıştır. 3 yıldır okul öncesi eğitime devam eden çocukların ifade edici dil puanları, 1 yıldır devam eden çocukların ifade edici dil puanlarından yüksek bulunmuştur.

48-66 aylık çocukların liderlik puanları ile ifade edici dil puanları arasında anlamlı bir ilişki olup olmadığına ilişkin Pearson Çarpım Momentler Korelasyon katsayısı hesaplanmış ve yapılan korelasyon analizine ilişkin bulgular Tablo 9'da gösterilmiştir.

Tablo 9. Erken Çocukluk Dönemi Liderlik Ölçeği’nin TEDİL İfade Edici Dil Alt Testi İle İlişkisine Yönelik Korelasyon Değerleri

\begin{tabular}{cccc}
\hline Değişkenler & $\mathbf{N}$ & $\mathbf{r}$ & $\mathrm{p}$ \\
\hline $\begin{array}{c}\text { Liderlik özellikleri } \\
\text { İfade Edici Dil }\end{array}$ & 92 & $\mathbf{0 , 4 8 4}$ & $\mathbf{0 , 0 0}$ \\
\hline
\end{tabular}

Tablo 9'da araştırmaya katılan 48-66 aylık çocukların Erken Çocukluk Dönemi Liderlik Ölçeği’nden aldıkları puanlar ile TEDİL ifade edici dil alt testi puanları arasındaki ilişkinin değerlendirmesi sonucu elde edilen bulgular yer almaktadır. Korelasyon katsayısının değeri; 0,00-0,30 arasında ise düşük düzeyde, 0,30-0,70 arasında ise orta düzeyde ve 0,70-1,00 arasında ise yüksek düzeyde bir ilişkinin var olduğu şeklinde yorumlanabilir (Büyüköztürk, 2002). Buna göre çocukların liderlik puanları ile TEDİL ifade edici dil alt testi puanları arasında 0,484 olan pozitif yönlü orta düzeyde anlamlı bir ilişki bulunmuştur $(\mathrm{p}<0,01)$. Bu bulguya göre çocukların liderlik puanları arttıkça ifade edici dil puanlarının da arttığı söylenebilir.

Çocukların liderlik özellikleri üzerinde ifade edici dil becerilerinin yordayıcı etkisini göstermeyi amaçlayan regresyon modeline ilişkin değerler Tablo 10'da sunulmuştur. 
Tablo 10. Çocukların Liderlik Özellikleri Üzerinde İfade Edici Dilin Etkisine İlişkin Regresyon Analizi Sonucu

\begin{tabular}{cccccc}
\hline Yordayan Değişken & $\mathbf{r}$ & $\mathbf{r}^{2}$ & Std. $\boldsymbol{\beta}$ & $\mathbf{t}$ & $\mathbf{F}$ \\
\hline İfade Edici Dil & 0,484 & 0,234 & 0,484 & 24,50 & 600,01
\end{tabular}

Tablo 10 incelendiğinde, regresyon modelinin anlamlı olduğu görülmektedir. Buna göre liderlik Özelliğindeki toplam varyansın \%23’ünün ifade edici dil becerisinden kaynaklandığı söylenebilir.

\section{SONUÇ ve TARTIŞMA}

Bu çalışmada okul öncesi dönem çocuklarının liderlik özellikleri ve dil becerileri çeşitli değişkenlere göre incelenerek liderlik özellikleri ile dil becerileri arasındaki ilişki araştırılmıştır.

Araştırma kapsamında çocukların liderlik puanlarının yüksek düzeyde olduğu tespit edilmiştir. Okul öncesi dönem çocukları için bu bulguyu destekleyecek bir araştırmaya rastlanmasa da literatürde farklı yaş grubu öğrencilerin liderlik özelliklerinin yüksek düzeyde olduğunu gösteren çalısmalar bulunmaktadır (Avc1, 2009; Birol, 2005; Cansoy, 2015; Durmuş, 2011; Ogurlu, 2012; Solmaz, 2017). Çocukların liderlik puanları yaş değişkeni açısından incelenmiş ve liderlik puan ortalamalarının, çocukların yaşlarına göre istatistiksel olarak anlamlı farklılık gösterdiği bulunmuştur. Bu fark yaşı 60-66 ay arasında olanlar ile yaşı 54-59 ay arasında olanlar arasındadır. Yaşı 60-66 ay arasında olanların liderlik puanları, yaşı 54-59 ay arasında olanlardan yüksektir. Parten (1933), bu çalışma sonucunda çıkan bulguya benzer bir şekilde yaş ilerledikçe liderlik gelişimine yönelik bir eğilim olduğunu, yaşı daha büyük olan çocuklarda yönlendiricilik faaliyetinin daha sık görüldüğünü belirtmiştir. French (1984), sınıf ortamında lider olan çocukların diğerlerine göre yaşça daha büyük olan çocuklar olduğu sonucuna varmıştır. Fakat bu araştırmada çıkan sonucun aksine Horn (1977), araştırmasında grupta yaşı daha büyük olan çocukların daha çok liderlik davranışı sergilemesi hipotezini destekleyecek veriler elde edememiştir. Bu nedenle ilgili değişken üzerinde daha fazla araştırmanın yapılmasına ihtiyaç duyulduğu söylenebilir.

Çocukların liderlik puan ortalamalarının cinsiyet değişkenine göre anlamlı farklılık gösterdiği saptanmıştır. Liderlik puan ortalamaları incelendiğinde kız çocuklarının liderlik puanları erkek çocuklarınınkinden daha yüksektir. Fu (1979) ve Sheldon (1996: akt. Soffler 2011) cinsiyet olasıllğ̆ının, dil becerileri ve etkililik açısından liderlik için önemli olduğunu belirtmişlerdir. Mawson (2010, 2011), işbirlikli oyunda liderlik ve kontrol ile ilgili cinsiyetler arasında farklilıklar olduğunu, yalnızca erkek çocukların oynadığı oyunlarda, liderliğin her zaman katılımcılar arasında net bir hiyerarşik statüye sahip diktatörlük tarzında olduğunu, kızlarda ise yönetmenlik tarzı bir liderlik olduğunu belirtmiştir. Bohlin (2000) ise, prososyal davranışlar ve organizasyonel liderlik boyutunda 
kızlar ve erkekler arasında anlamlı bir farklılık olduğu sonucuna ulaşmıştır. Fakat bu çalışmadan elde edilen bulgunun aksine Parten (1933), Trawick-Smith (1992) ve Harrison, Rawls ve Rawls (1971) okul öncesi dönemde liderlikte cinsiyet farklılıklarının önemsiz olduğunu belirtmiştir. Bu sonucun kızlar ve erkekler arasındaki dil gelişimi farklılıklarının başkalarını etkileme üzerindeki gücünden kaynaklandığı düşünülmektedir.

Çocukların liderlik puan ortalamalarının okul öncesi eğitim kurumuna devam süresi değişkenine göre anlamlı farklılık gösterdiği saptanmıştır. Bu farklılık daha uzun süre okul öncesi eğitim alma durumunun lehinedir. Yani 3 yıl ve daha fazla süre okul öncesi eğitim alan çocukların puanları, 1 yıldır okul öncesi eğitim alan çocukların puanlarından daha yüksektir. Liderlik ile okul öncesi eğitim alma süresi arasında doğrudan ilişkili bir çalışmaya rastlanmasa da çocukların akranları ile kurduğu ilişkiler ve etkileşimler açısından önemli olduğunu gösteren çalışmalar mevcuttur. Schwartz, Strickland ve Krolick (1974), 3 buçuk yaş çocukları üzerinde yaptıkları çalışmada 22 aylıktan önce okul öncesi eğitim almaya başlayan çocuklanın daha çok olumlu etkiler, daha az gerginlik ve daha fazla sosyal etkileşim kurdukları sonucuna varmıstır. Howes (1991) okul öncesi eğitim alma süresinin çocukların akranları ile ilişkilerini (hem pozitif hem de negatif yönde) etkilediğini belirtmiştir (Akt. Bohlin, 2000). Okul öncesi eğitim almanın çocuklar üzerindeki olumlu etkilerini gösteren çalışmaların aksine Clarke-Stewart, Gruber ve Fitzgerald (1994), diğer çocuklarla birlikte olmanın, çocuklara akran etkileşimlerinde başarıly kullanabilecekleri toplumsal beceriler konusunda birikim vermek için tek başına yeterli olmadığını belirtmiştir. Bu sonucun okul öncesi eğitimden faydalanma düzeyinin artmasına bağlı olarak çocukların sosyal ortamlarda daha fazla deneyim kazanmasından kaynaklandığı söylenebilir.

Araştırma sonuçlanına göre çalışma grubundaki çocukların TEDİL'den aldıkları ifade edici dil puanlarının yaş değişkenine göre istatistiksel olarak anlamlı farklılık göstermediği bulunmuştur. Bu araştırmadan çıkan sonuca benzer şekilde Çat Şahin (2008), okul öncesi eğitim kurumuna devam eden 5-6 yaş grubu çocukların dil gelişim düzeylerinin yaş değişkenine bağlı olarak anlamlı bir farklılık göstermediği; Gürocak (2007) da anasınıfına devam eden 60-72 ay çocukların dil gelişimi ve ince motor gelişimi açısından değerlendirilmesiyle ilgili betimsel çalışmasında öğrencilerin dil gelişimlerinin yaşlarına göre farklılık göstermediği sonucuna ulaşmıştır. İlgili literatür incelendiğinde yaş değişkenin farklılaşma yarattı̆̆ı çalışmalara da rastlanmaktadır. Koçak, Ergin, Yalçın (2014) 5-6 yaş çocukları ile, Yıldırım (2008) ise okul öncesi eğitim kurumlarından yararlanmayan 4-5 yaş çocukları ile yaptığı araştırmasında yaşın anlamlı farklılaşma yarattı̆̆1 sonucuna ulaşmıştır. $\mathrm{Bu}$ sonucun çalışma grubundaki çocukların özelliklerinden kaynaklandığı düşünülmektedir.

Çocukların TEDİL'den aldıkları ifade edici dil puanlarının cinsiyet değişkenine göre istatistiksel olarak anlamlı farklılık gösterdiği bulunmuştur. Bu farklılık kız çocuklarının lehinedir. Yani kız 
çocuklarının ifade edici dil puan ortalamaları, erkek çocuklarınınkinden yüksektir. Alanyazın incelendiğinde çocukların dil becerilerindeki cinsiyet farklılıklarının kız ve erkek çocukların lehine farklılık gösterdiği çalışmalara rastlanmıştır. Koçak, Ergin, Yalçın (2014), Özmermer (2008) ve Yıldırım Doğru, Alabay ve Kayılı (2010) erkek çocuklarının dil puanlarının daha yüksek olduğu sonucuna varmıştır. Bu sonuçlardan farklı olarak ise Erdoğan, Şimşek Bekir ve Erdoğan Aras (2005) ve Çat Şahin (2008) ise çalışmalarında çocukların dil puanlarında cinsiyete göre anlamlı bir farklılık olmadığı sonucunu bulmuştur. Bu sonucun dili kullanmada kız çocukları ile erkek çocukları arasındaki farklılıklardan kaynaklandığı söylenebilir.

Çalışma grubundaki çocukların TEDİL'den aldıkları ifade edici dil puanlarının okul öncesi eğitim kurumuna devam süresi değişkenine göre istatistiksel olarak anlamlı farklılık gösterdiği bulunmuştur. Bu farklılık daha uzun süre okul öncesi eğitim alma durumunun lehinedir. Yani 3 yll ve daha fazla süre okul öncesi eğitim alan çocukların puanları, 1 yıldır okul öncesi eğitim alan çocukların puanlarından daha yüksektir. Çat Şahin (2008) çocukların dil gelişim düzeylerinin okul öncesi eğitim kurumuna devam süresine göre farklılaştı̆̆1, okul öncesi eğitim kurumuna 3 yıl ve daha fazla süreyle devam eden çocukların dil gelişimlerinin diğer çocuklardan daha iyi olduğu sonucuna varmıştır. Öztürk (1995) okul öncesi eğitim kurumuna giden ve gitmeyen ilkokul birinci sınıf öğrencilerinin alıcı ve ifade edici dil düzeylerini incelediği araştırmada okul öncesi eğitime giden çocukların alıcı ve ifade edici dil düzeylerinin okul öncesi eğitime gitmeyenlerden daha yüksek olduğu sonucuna varmıştır. Erdoğan, Şimşek Bekir ve Erdoğan Aras (2005), ana sınıfina devam süresine göre Peabody Resim Kelime Testi puanlarının ortalama değerleri karşılaştırması sonucunda anlamlı bir farklılığın olduğunu tespit etmişlerdir. Yıldız, Şen ve Coşkun’un (2006) 5-6 yaş grubu çocukların üst dil becerilerini inceleyen araştırmalarında; okul öncesi eğitim kurumuna devam eden çocukların üst dil beceri puan ortalamalarının, okul öncesi eğitim kurumuna devam etmeyen öğrencilerden daha yüksek olduğu sonucu elde edilmiştir. Bu sonucun çocukların okul öncesi eğitim ortamlarındaki zengin uyarıcı çevrede edindikleri tecrübelerden kaynaklandığı düşünülmektedir.

Çocukların liderlik özellikleri ile dil becerileri arasında anlamlı bir ilişki olup olmadığına ilişkin yapılan analiz sonucunda çocukların Erken Çocukluk Dönemi Liderlik Ölçeği ile TEDİL İfade Edici Dil Alt Testi'nden aldıkları puanlar arasında orta düzeyde pozitif yönlü anlamlı bir ilişki bulunmuştur. Yani çocukların liderlik puanları arttıkça dil puanlarında da artış görülmüştür. Ayrıca yapılan regresyon analizine göre liderlik özelliğindeki toplam varyansın \%23'ünün ifade edici dil becerisinden kaynaklandığı söylenebilir. Bu çalışmadan elde edilen sonuca benzer olarak Perez, Chassin, Ellington ve Smith'in (1982) çalışmasında sosyometri testinde lider olarak tanımlanan çocukların Peabody Resim Kelime Testinden yüksek puanlar aldığı belirtilmiştir. Rosenthal (1957) da sosyometrik statü ve kullanılan dil arasındaki ilişkiyi incelediği çalışmasında sosyometrik statüsü yüksek olan çocukların dil açısından daha aktif, konuşkan ve sözcük kullanımı konusunda daha 
değsşken olduğunu, ayrıca daha "popüler" çocukların üstün kalitede ve sosyal açıdan yararlı bir dil kullandığını belirtmiştir. Çocukların iletişim becerileri, özellikle sözel bağlantının kurulmasına katkısı olan beceriler, sosyal etkileşimde kritik öneme sahip olabilir (Gottman ve Parkhurst, 1980; Mueller, 1972. akt; Black ve Hazen, 1990). Liderin önemli bir niteliği, sosyalleşme, yani diğer çocuklarla hızlı bir şekilde bağlantı kurma becerisidir. Bu bağlantıların kurulmasında dil oldukça önemli bir yere sahiptir çünkü liderin açık ve anlaşılır olarak kendini ifade edebilmesi bu bağlantının kurulmasını kolaylaştırır. Yaşa bakılmaksızın tüm liderler çok iyi iletişim becerilerine sahip olmalıdır, çünkü liderin daha net, akıcı ve dolayısıyla takipçilerine daha ikna edici olmasını sağlayacaktır. Dil, fikirleri, duyguları daha kolay iletebilmeyi ve yön verebilmeyi sağlar. Bu nedenle bu çalışmada da liderlik ile dil becerileri arasında pozitif bir ilişki bulunmuş olabilir.

Okul öncesi dönem çocuklarının liderlik özellikleri ile dil becerilerinin incelendiği bu araştırmada;

- Okul öncesi dönem çocuklarının liderlik özellikleri ile dil becerileri arasında orta düzeyde pozitif yönlü anlamlı bir ilişki sonucuna varılmıştır.

- Çocukların liderlik puanlarının yaş, cinsiyet ve okul öncesi eğitim kurumuna devam süresi değişkenine göre farklılık gösterdiği tespit edilmiştir.

- Çocukların dil puanlarının cinsiyet ve okul öncesi eğitim kurumuna devam süresi değişkenine göre farkl1lık gösterdiği, ancak yaşa göre farkl11ık göstermediği belirlenmiştir.

\section{Öneriler}

Çocukların liderlik özellikleri ile dil becerileri arasında ilişki olduğu için öğretmenler hem liderlik konusunda hem de dilin kullanımı ve çocuklarda bu becerilerin gelişiminin desteklenmesi açısından önemli bir rol model olarak bu konularla ilgili kurs ve seminerlere katılabilir ve ayrıca eğitim programlarına çeşitli etkinlikler dahil edebilir.

Gelecek çalışmaların İstanbul dışındaki farklı illerde ve daha geniş öğrenci grupları ile, daha farklı sosyoekonomik düzey ve kültürden gelen çocuklarla ve ayrıca liderlik üzerinde etkili olabilecek başka pek çok etkenin ve bu etkenlerin birlikte değişimlerine ilişkin çalışmalar yapılması önerilebilir.

$\mathrm{Bu}$ araştırma nicel araştırma yöntemleri kullanılarak yürütülmüştür. Nitel araştırma yöntemleri kullanarak da yeni araştırmalar yürütülebilir. Boylamsal çalışmalar ile sonuçların uzun süreli etkisi gözlenebilir.

\section{KAYNAKÇA}

Adcock, D. \& Segal, M. (1983). Making friends: Ways of encouraging social development in young children. Englewood Cliffs. NJ: Prentice-Hall. 
Addison, L., Oliver, A. I. \& Cooper, C. (1987). Developing leadership potential in gifted children and youth. Eric Document Reproduction Service. No. Ed 285310.

Avc1, B. (2009). Öğrencinin liderliği. Yüksek lisans tezi, Gaziosmanpaşa Üniversitesi, Sosyal Bilimler Enstitüsü, Tokat.

Barthold, K. S. (2014). The Emergence of Leadership in Children: The Role of Play, Athletics, and School. CMC Senior Theses. Paper 859. http://scholarship.claremont.edu/cmc_theses/859 adresinden 09/06/2020 tarihinde erişilmiştir.

Black, B. \& Hazen, N. L. (1990). Social status and patterns of communication in acquainted and unacquainted preschool children. Developmental Psychology, 26, 379-387.

Birol, Z. H. (2005). Fen lisesi ve sosyal bilimler lisesi ögrencilerinin mükemmeliyețilik, benlik saygısı, liderlik özelliklerinin incelenmesi. Yüksek lisans tezi, Karadeniz Teknik Üniversitesi, Sosyal Bilimler Enstitüsü, Trabzon.

Bohlin, L. C. (2000). Determinants of young children's leadership and dominance strategies during play. PhD Thesis. Indiana University, Department of Educational Psychology.

Cansoy, R. (2015). Türkiye'de ortä̈gretim okullarndaki ögrencilerin gençlik liderlik özelliklerinin incelenmesi. Doktora Tezi, Eskişehir Osmangazi Üniversitesi, Eğitim Bilimleri Enstitüsü, Eskişehir.

Clarke-Stewart, K. A., Gruber, C. P. \& Fitzgerald, L. M. (1994). Children at home and in day care. Hillsdale, NJ: Lawrence ErlbaumAssociates.

Creswell, J. W. (2005).Educational research planning, conducting and evaluating quantitative and quantative research. USA: Pearson Prentice.

Çat Şahin, A. (2008). Okul öncesi eğitim kurumuna devam eden 5-6 yas grubu çocuklarn dil gelişimi ile annelerin okuma ilgi ve alışkanhlklar arasındaki ilişkinin çeşitli değlşkeenler açısından incelenmesi. Yüksek Lisans Tezi, Abant İzzet Baysal Üniversitesi, Sosyal Bilimler Enstitüsü, Bolu.

Durmuş, Ö. (2011). İlkëgrretim ve lise ögrencilerinde görülen liderlik davranışlarmın araştırlması. Yüksek lisans tezi, Çanakkale 18 Mart Üniversitesi, Sosyal Bilimler Enstitüsü, Çanakkale.

Erdoğan, S., Şimşek Bekir, H. \& Erdoğan Aras, S. (2005). Alt sosyoekonomik bölgelerde ana sınıfina devam eden 5-6 yaş grubundaki çocukların dil gelişim düzeylerine bazı faktörlerin etkisinin incelenmesi. Cukurova Üniversitesi Sosyal Bilimler Enstitüsü Dergisi, 14(1), 232-246.

French, D. C. (1984). Children's knowledge of the social functions of younger, older, and sameage peers. Child Development, 55(4), 1429-1433.

Fu, V. R. (1970). A nursery school leadership observation schedule and a nursery school leadership rating scale. Greensboro, NC: University of North Carolina.

Fu, V. R. (1979). Preschool leadership-followership behaviors. Child Study Journal, 9(2), 133- 140.

Fu, V. R., Canaday, H. \& Fu, D. (1982). Creativity and leadership in preschoolers. The Journal of Genetic Psychology, 141(2), 291-292. 
Gertner, B. L., Rice, M. I. \& Hadley, P. A. (1994). Influence of communicative competence on peer preferences in a preschool classroom. Journal of Speech and Hearing Research, Volume 37, 913-923.

Gürocak Ünal, S. (2007). Anasmifina devam eden 60-72 ay çocuklarn dil gelisimi ve ince motor gelisimi açısından değerlendirilmesi. Yüksek Lisans Tezi, Abant İzzet Baysal Üniversitesi, Sosyal Bilimler Enstitüsü, Bolu.

Guven, O. S. (2014). İki dil testinin (TEDIL ve TODIL) tipik ve atipik dil gelişimi gösteren çocuklarda ayırt ediciliğinin incelenmesi. Doktora Tezi, Anadolu Üniversitesi, Sağl1k Bilimleri Enstitüsü, Eskişehir.

Hadley, P. A. \& Rice, M. L. (1991). Conversational responsiveness of speech and language-impaired preschoolers. Journal of Speech and Hearing Research, 34, 1308-1317.

Harrison, C. W., Rawls, J. \& Rawls, D. (1971). Differences between leaders and non-leaders in sixto-eleven-year-old children. Journal of Social Psychology, 84, 269-272.

Hazen, N. A. \& Black, B. (1989). Preschool peer communication skills: The role of social status and interaction context. Child Development, 60(4), 867-876.

Hensel, N. H. (1991). Social leadership skills in young children. Roeper Review, 14(1), 4-6.

Horn, L. M. (1977). A correlational study of leadership among preschool children. Master Thesis, Kean College of New Jersey.

Howes, C. (1988). Peer interaction of young children. Monographs of the Society for Research in Child Development, 53 (1,Serial No. 217).

Karasar, N. (2014). Bilimsel araștırma yöntemi. Ankara: Nobel.

Karnes, F. \& Bean, S. (1990). Developing leadership in gifted youth. Council for Exceptional Children \& ERIC Clearinghouse on Handicapped and Gifted Children. ERIC Digest \#E485.

Karnes, F. \& Bean, S. (1996). Leadership and the gifted. Focus on Exceptional Children, 29(1), 1-12.

Kemple, K. M. (1991). Research in review: Preschool children's peer acceptance and social interaction. Young Children, 46(5), 47-54.

Koçak, N., Ergin, B. \& Yalçın, H. (2014). 60-72 Aylık çocukların türkçe dil kullanımı düzeyleri ve etki eden faktörlerin incelenmesi. KMÜ Sosyal ve Ekonomik Arasstrmalar Dergisi, 16(II), 100106.

Koçel, T. (2010). Isletme yöneticiligi. Istanbul: Beta Yayınc1lık.

Lee, S. Y., Recchia, S. \& Shin, M. S. (2005). "Not the same kind of leaders": Four young children's unique ways of influencing others. Journal of Research in Childhood Education, 20(2), 132-148.

Manning, S. (2005). Young leaders: Growing through mentoring. Gifted Child Today, 28(1), 14- 20.

Mawson, B. (2010). Gender and leadership styles in children's play. Australasian Journal of Early Childhood, 35(2), 115-124. 
Mawson, B. (2011). Children's leadership strategies in early childhood. Journal of Research in Childhood Education, 25(4), 327-338.

Mullarkey, L. S., Recchia, S. L., Lee, S. Y., Shin, M. S. \& Lee, Y. J. (2005). Manipulative managers and devilish dictators: Teachers' perspectives on the dilemmas and challenges of classroom leadership. Journal of Early Childhood Teacher Education, 25, 123-129.

Murphy, S. E., \& Johnson, S. K. (2011). The benefits of a long-lens approach to leader development: Understanding the seeds of leadership. The Leadership Quarterly, 22(1), 459470.

Ogurlu, Ü. (2012). Liderlik becerileri geliștirme programmn üstün zekâh olan ve olmayan ögrencilerin liderlik becerilerine etkisi. Doktora Tezi. İstanbul Üniversitesi, Sosyal Bilimler Enstitüsü, İstanbul.

Özalp, İ., Şahin, M., Berberoğlu, G. \& Ceylan, R. (2004). Yönetim ve organizasyon. Celil Koparal (Ed.). Eskişehir: Anadolu Üniversitesi Yayını No:1457.

Özmermer, N. (2008). Calışan annelerin ve çalıs̆mayan annelerin anasmufina devam eden 5-6 yas çocuklarnmn dil gelişim farklhlıklarmm kearşlaştırlması. Yüksek Lisans Tezi, Beykent Üniversitesi, Sosyal Bilimler Enstitüsü, İstanbul.

Öztürk, H. (1995). Okul öncesi eğitim kurumlarna giden ve gitmeyen ilkokul birinci smaf ögrencilerinin ahcı ve ifade edici dil düreyleri. Yüksek Lisans Tezi, Gazi Üniversitesi, Sosyal Bilimler Enstitüsü, Ankara.

Parten, M. (1933). Leadership among preschool children. The Journal of Abnormal and Social Psychology, 27(4), 430-440.

Perez, G., Chassin, D., Ellington, C. \& Smith, J. (1982). Leadership giftedness in preschool children. Roeper Review, 4(3), 26-28.

Place, K. S. \& Becker, J. A. (1991). The influence of pragmatic competence on the likability of grade-school children. Discourse Process, 14, 227-243.

Rice, M. L. (1993). Don't talk to him; he's weird: A social consequences account of language and social interactions. In Kaiser, A. P. \& Gray, D. B. (Eds.), Enhancing children's communication: Research foundations for intervention (pp. 139-158). Baltimore, MD: Brookes Publishing Company.

Rice, M. L., Sell, M. A. \& Hadley, P. A. (1991). Social interactions of speech- and language-impaired children. Journal of Speech and Hearing Research, 34, 1299-1307.

Roets, L. F., Ed. (2000). Leadership for ages 4-8: Identification and talent development. Des Moines, IA: Leadership Publishers.

Rosenthal, F. (1957). Some relationships between sociometric position and language structure of young children. Journal of Educational Psychology, 48(8), 483-497.

Schwartz, J., Strickland, R. \& Krolick, G. (1974). Infant day care: Behavioral effects at preschool age. Developmental Psychology. 10. 502-506. 
Shin, M. S., Recchia, S. L., Lee, S. Y., Lee, Y. J. \& Mullarkey, L. S. (2004). Understanding early childhood leadership: Emerging competencies in the context of relationships. Journal of Early Childhood Research, 2(3), 301-316.

Sisk, D. A. \& Rosselli, H. C. (1996). Leadership: A special kind of giftedness. Unionville, NY: Trillium Press.

Soffler, A. A. (2011). What is the nature of children's leadership in early childhood education settings? A Grounded Theory. PhD Thesis, Colorado State University, Fort Collins, Colorado.

Solmaz, H. (2017). Okul öncesi çocuklarnm liderlik becerilerinin geliştirilmesi konusunda deneysel bir çalısma: şimdinin küüükleri, geleceğin büyük liderleri. Yüksek Lisans Tezi, Çanakkale Onsekiz Mart Üniversitesi, Eğitim Bilimleri Enstitüsü, Çanakkale.

Topbaş, S. \& Güven, S. (2013). Türkşe erken dil gelisimi testi (TEDIL). Ankara: Detay Yayıncilık.

Yıldırım, A. (2008). Okul öncesi eğitim kurumlarndan yararlanamayan 4-5 yas çocuklarmmn dil gelişimini etkileyen faktörlerin incelenmesi (Konya ili örneği). Yüksek Lisans Tezi, Selçuk Üniversitesi, Sosyal Bilimler Enstitüsü, Konya.

Yıldırım Doğru, S. S., Alabay, E. \& Kayıll, G. (2010). Normal gelişim gösteren ve öğrenme güçlüğü olan çocukların sözcük dağarcığ1 ile dili anlama düzeylerinin belirlenmesi. Elementary Education Online, (6)3, 829-840.

Yıldız, C., Şen, S. \& Coşkun, R. (2006). Okul öncesi eğitim kurumlarına devam eden ve etmeyen 56 yas çocukların üst dil becerilerin incelenmesi (Özetler). Ulusal Eğitim Bilimleri Kongresi, 13- 15 Eylül, 942 Muğla. 